\title{
Haematological indicators in hybrid mallard ducks (Anas platyrhynchos) with regard to the use of meal from whole white lupin seeds in their diet
}

\author{
David Zapletal ${ }^{1}$, Lenka Kudělková ${ }^{1}$, Vlastimil Šimek ${ }^{1}$, Petra Jakešová1, \\ Miroslav Macháček ${ }^{1}$, Eva Straková ${ }^{2}$ Pavel Suchý ${ }^{1}$ \\ University of Veterinary and Pharmaceutical Sciences Brno, Faculty of Veterinary Hygiene and Ecology, \\ ${ }^{1}$ Department of Animal Husbandry and Animal Hygiene, \\ ${ }^{2}$ Department of Animal Nutrition, Brno, Czech Republic
}

Received May 25, 2017

Accepted October 2, 2017

\begin{abstract}
The objective of our study was to assess the effect of replacing soybean meal with the meal from whole white lupin seeds (Lupinus albus) of the Zulika variety in diets on selected haematological indicators in 40-day-old fattened hybrid mallard ducks. A total of 180 Cherry Valley ducks were divided into three groups (E1, E2, and control). The control group was fed a diet containing soybean meal. Soybean meal replaced with $50 \%$ and $100 \%$ meal of white lupin seeds were used in group E1 and group E2, respectively. At the end of the fattening, 12 ducks (6 males and 6 females) were randomly selected from each group for a haematological examination. From the result of this study, it is clear that the effect of the diet was found only on the slightly varying number of white blood cells and on the proportion of monocytes. Ducks of group E2 showed a slight increase in the total number of leukocytes which was accompanied by a decrease in the percentage share of monocytes $(P<0.05)$. Based on the results, it can be claimed that the replacement of soybean meal with meal from the Zulika variety of whole white lupin seeds in the diet did not have a negative effect on the determined blood indicators. Therefore, whole white lupin seeds were successfully used as the important protein component of the diet for fattening hybrid mallard ducks.
\end{abstract}

Cherry Valley duck, soybean meal, Lupinus albus, fattening, whole blood

The most common vegetable protein source in poultry feed is soybean meal. Recently, however, the use of home-grown legume seeds is becoming increasingly important as an alternative source to using soybean products, especially in climate areas that are less favourable for the production of soybean (Nalle et al. 2012; Kaczmarek et al. 2016). In this regard, home-grown white lupin seeds (Lupinus albus) may effectively be used as an important vegetable protein source in feed used for the fattening of various food animals (Straková et al. 2006; Suchý et al. 2010; Hernández and Roman 2016).

As for duck meat production in the Czech Republic nowadays, mainly the mallard duck hybrids are used for this purpose because of their short-term fattening, performance, carcass quality, and adaptability to indoor housing conditions.

The haematological examination of birds is used as part of the evaluation of their health condition, the same as in mammals. It is especially used for the diagnosis and monitoring of the course of the disease, evaluating the effectiveness of therapy or prognosis of the disease. Another advantage of performing a haematological examination can also be seen in defining physiological reference values of specific indicators in a number of bird species. However, within a specific bird species, there are many particular physiological factors which could influence the haematological profile of healthy birds. These are mainly the nutrition, breed, age, sex, moulting, laying season, and geographical location (Král and Suchý 2000; Okeudo et al. 2003; Olayemi and Arowolo 2009; Knotková et al. 2013). A lack of the amount of relevant physiological values for the specific production

Address for correspondence:

Prof. Ing. David Zapletal, Ph.D.

Department of Animal Husbandry and Animal Hygiene

Faculty of Veterinary Hygiene and Ecology

University of Veterinary and Pharmaceutical Sciences Brno

Palackého tř. 1946/1, 61242 Brno, Czech Republic 
type or sexual maturity are among the causes which could possibly make it difficult to interpret the results of the haematological examination in birds (Král and Suchý 2000). In addition, for a specific bird species, it is typical that there may be large variability in their leukogram. Whereas, especially the reference values of the white blood count are often stated within a much wider range than in domestic mammals (Knotková et al. 2013).

Previous studies revealed that different legume seeds used as dietary protein sources sometimes may affect haematological profile of poultry and other food animals (Obun 2013; Iqbal et al. 2016), whereas variations in haematological indicators are associated with a wide variety of nutritional and anti-nutritional factors of particular feed components (Osuigwe et al. 2007). Therefore, the objective of our study was to assess the effect of replacing soybean meal with meal from the whole white lupin seeds of Zulika variety in the diets on selected haematological indicators of fattened hybrid mallard ducks.

\section{Materials and Methods}

The experimental procedures were approved by the Animal Welfare Committee of the University of Veterinary and Pharmaceutical Sciences (UVPS) Brno, project no. 57/2015/2220/FVHE.

\section{Animals and nutrition}

The experiment was performed in the accredited experimental stable of the Department of Animal Nutrition and the Department of Animal Husbandry and Animal Hygiene of UVPS Brno, under controlled housing conditions.

A total of 180 (90 $\circ$ and $90 \AA$ ) Cherry Valley hybrid mallard ducks, which were equally divided into three groups [experimental 1 (E1), experimental 2 (E2), and control (C)], were used in the experiment. Ducklings from each group were housed in 4 floor pens (15 birds/pen) covered with wood shavings. Ducks in group $\mathrm{C}$ were fed a diet containing soybean extract meal as the main protein component of the diet. Soybean meals replaced with $50 \%$ and $100 \%$ meal of white lupin seeds (Zulika variety) were used in group E1 and group E2, respectively. A 4-phase feeding programme was used, where the ducks were fed a starter (VKCHS) up to the $9^{\text {th }}$ day of age, grower I $(\mathrm{VKCH} 1)$ from the $10^{\text {th }}$ to the $18^{\text {th }}$ day of age, grower II $(\mathrm{VKCH} 2)$ from the $19^{\text {th }}$ to the $34^{\text {th }}$ day of age, and the finisher $(\mathrm{VKCH} 3)$ from the $35^{\text {th }}$ day to the end of the experiment at the $40^{\text {th }}$ day of age. The complete feed mixtures were composed of the following components: maize, wheat, soybean extract meal or meal from whole white lupin seeds, soy oil, animal fat, threonine, methionine, lysine, monocalcium phosphate, $\mathrm{NaCl}$, and enzymes. In feed, we determined the content of dry matter, crude protein, crude fat, crude starch, crude fibre, acid-detergent fibre (ADF), neutral-detergent fibre (NDF), acid-detergent lignin (ADL), crude ash, nitrogen-free extractives (NFE), organic matter (OM) and gross energy. Dry matter was determined by weight upon drying the sample at $105{ }^{\circ} \mathrm{C}$ under prescribed conditions. Crude protein was determined by Kjeldahl method using Buchi analyser (Centec Automatika, Czech Republic). Crude fat was determined by Soxhlet method. Crude starch was determined using the Automatic Digital Polarimetr P3002RS (Krüss, Germany). Crude fibre, ADF, NDF and ADL were determined by ANKOM 220 fibre analyzer (O.K. Servis BioPro, Czech Republic). Crude ash was determined by weighing the sample after incineration at $550{ }^{\circ} \mathrm{C}$ under prescribed conditions. Gross energy was determined by the Kalorimetr AC500 (LECO, s.r.o., Czech Republic). Then we calculated the NFE and OM content. Chemical compositions of the diets are presented in Table 1, while nutrient compositions of diets corresponded with general nutrition requirements for hybrid mallard ducks in the particular age. Feed was fed to the ducks in the form of crumble-pellets and entire pellets till the $9^{\text {th }}$ day of age and from the $10^{\text {th }}$ to the $40^{\text {th }}$ day of age, respectively. During the course of the entire experiment, feed and water were available ad libitum.

\section{Blood sampling and haematological analysis}

At the end of the fattening (day 40) 12 ducks ( 6 q and 6 ) per group (3 birds/pen) were randomly selected for a haematological examination. The ducks were weighed and then their blood was taken by puncturing the vena basilica. The blood samples were stabilized by heparin, while haematological indicators were determined in the whole blood immediately after sampling.

The count of red blood cells (RBC) and white blood cells (WBC) was determined manually using a haemocytometer, while Natt and Herrick's solution was used as a diluting fluid. The haematocrit value (HCT) was performed by the microhaematocrit method after centrifuging. The haemoglobin concentration (HGB) was determined using the cyanohaemoglobin method with Drabkin's solution. The following erythrocyte indicators were determined: mean corpuscular volume (MCV), mean corpuscular haemoglobin $(\mathrm{MCH})$, and mean corpuscular haemoglobin concentration (MCHC).

The blood smears were stained using LEUCODIFF 200 (Erba Lachema s.r.o., Czech Republic). Differential leukocyte counts were performed manually categorizing and counting according to the morphologic and staining characteristics, while the first $100 \mathrm{WBC}$ observed on the each stained blood smear were counted and classified. Determination was performed by microscopic examination under a $\times 100$ objective lens with immersion oil. 


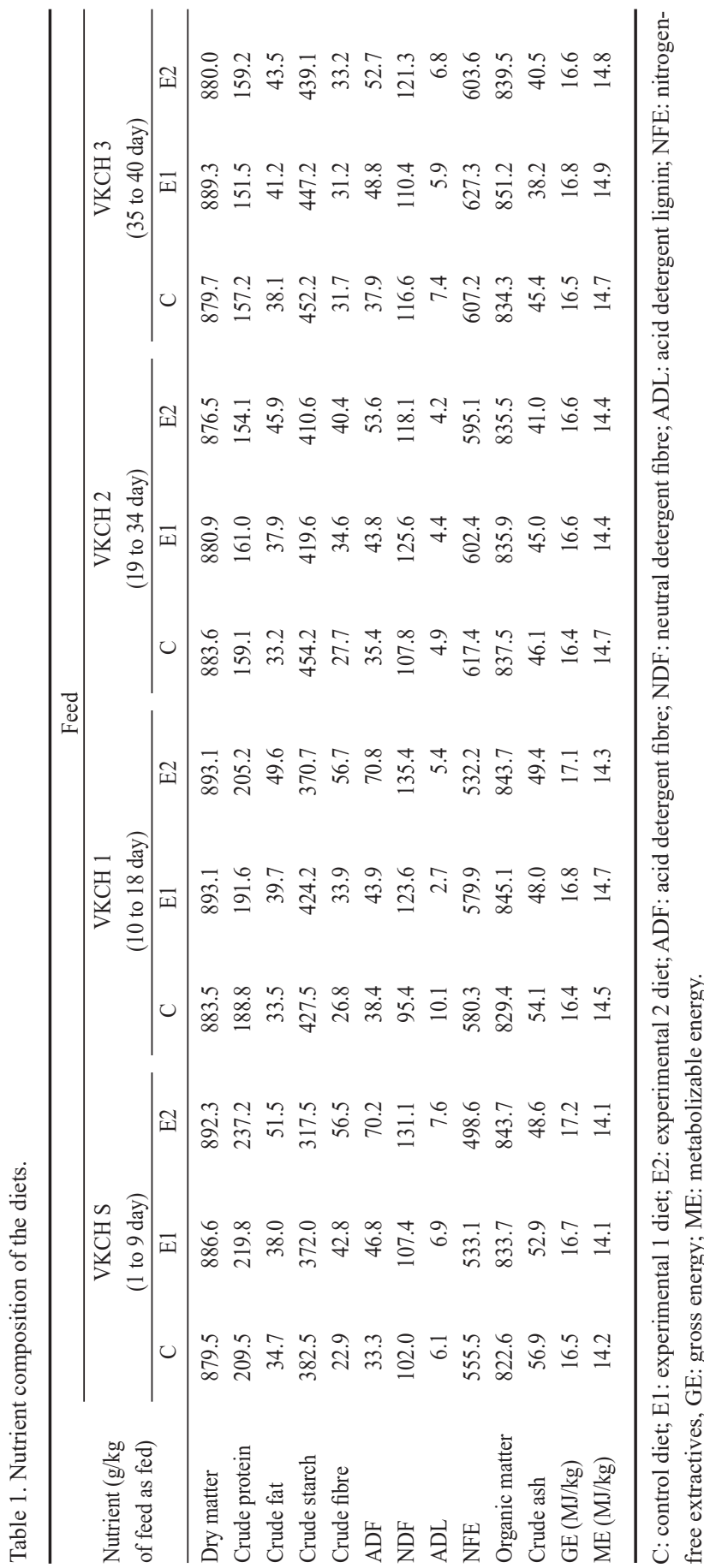

The following indicators of leukogram patterns were determined: the percentage share of granulocytes (GRA), lymphocytes (LYM), and monocytes (MON) from the total number of WBC.

Statistical analysis

Statistical analyses were performed using the STATISTICA CZ version 10 software (StatSoft Inc. 2011). The arithmetic mean and its $95 \%$ confidence interval were determined in the live weight (LW), RBC, WBC, HCT, $\mathrm{HGB}, \mathrm{MCV}, \mathrm{MCH}$, and $\mathrm{MCHC}$, while the arithmetic mean and the standard error of the mean (SEM) were determined in the proportion of GRA, LYM and MON. Shapiro-Wilk test was used to test normal distribution of the data within respective dietary groups; normality was found in all assessed indicators. One-way ANOVA was used to determine differences in all haematological indicators. Differences among dietary groups were analysed for significance using Tukey's test.

\section{Results}

Values of physiological ranges for determined haematological indicators in mallard ducks are stated in Table 2.

The mean LW and selected haematological indicators of the mallard ducks for both sexes in the respective groups are presented in Table 3. The live weight of ducks at the age of 40 days did not differ among the respective groups $(P>0.05)$. The situation was also similar in the case of the determined haematological indicators, except for the WBC $(P<0.05)$. As for the WBC, its highest value was found in mallard ducks in group E2, where this value was significantly higher than in the mallard ducks in group E1 $(P<0.05)$. 
Table 2. Reference haematology values for mallard ducks.

\begin{tabular}{lc}
\hline Indicator & Range \\
\hline RBC $\left(\times 10^{12} / 1\right)$ & $2.0-3.4$ \\
HCT $(1 / 1)$ & $0.298-0.668$ \\
HGB $(\mathrm{g} / 1)$ & $114.0-156.0$ \\
MCV (fl) & $148.0-200.0$ \\
MCH $(p g)$ & $30.0-78.0$ \\
MCHC $(\mathrm{g} / 1)$ & $292.0-316.0$ \\
WBC $\left(\times 10^{9} / 1\right)$ & $23.4-24.8$ \\
Granulocytes $(\%)$ & $31.0-42.0$ \\
Lymphocytes $(\%)$ & $54.0-66.0$ \\
Monocytes $(\%)$ & $2.0-4.0$
\end{tabular}

Combined data from Doubek et al. (2003); Campbell et al. (2010)

RBC: red blood cells; HCT: haematocrit; HGB: haemoglobin; MCV: mean corpuscular volume; $\mathrm{MCH}$ : mean corpuscular haemoglobin; MCHC: mean corpuscular haemoglobin concentration; WBC: white blood cells. cottonseed meal replacement in the diet did not have an effect on the values of the RBC, which is in accordance with the findings in our study, where meal from whole white lupin seeds was used to replace soybean meal. Besides, in our study, the values of RBC in the mallard ducks within all monitored groups were slightly higher than those found by $\mathrm{He}$ et al. (2013) in 35-day-old Cherry Valley hybrid ducks. On the other hand, the values of RBC that we found are somewhat lower than the values found by Eze et al. (2014) in 21-day-old domestic mallard ducks. Concerning the values of the HCT, the values that we found corresponded to the values found by He et al. (2013). Examination of the HCT is typically performed as a part of the haematological examination, given that the HCT value

Table 3. Haematological indicators and live weights of fattened mallard ducks in relation to the diet.

\begin{tabular}{|c|c|c|c|c|c|c|c|}
\hline \multirow{3}{*}{ Item } & \multicolumn{6}{|c|}{ Diet } & \multirow{3}{*}{ Significance } \\
\hline & \multicolumn{2}{|c|}{ Control } & \multicolumn{2}{|c|}{ Experimental 1} & \multicolumn{2}{|c|}{ Experimental 2} & \\
\hline & Mean & $\mathrm{CI}$ & Mean & $\mathrm{CI}$ & Mean & CI & \\
\hline Number & \multicolumn{2}{|c|}{12} & \multicolumn{2}{|c|}{12} & \multicolumn{2}{|c|}{12} & \\
\hline LW (kg) & 3.35 & $3.24-3.47$ & 3.30 & $3.20-3.41$ & 3.29 & $3.22-3.36$ & ns \\
\hline $\mathrm{RBC}\left(\times 10^{12} / 1\right)$ & 2.62 & $2.350-2.882$ & 2.61 & $2.311-2.914$ & 2.80 & $2.269-3.327$ & ns \\
\hline $\operatorname{HCT}(1 / 1)$ & 0.355 & $0.3386-0.3714$ & 0.350 & $0.3324-0.3676$ & 0.340 & $0.3205-0.3595$ & ns \\
\hline HGB (g/l) & 118.4 & $112.68-124.04$ & 115.7 & $110.23-121.22$ & 113.9 & $105.71-122.17$ & ns \\
\hline MCV (fl) & 138.6 & $124.60-152.58$ & 137.8 & $120.73-154.88$ & 130.2 & $108.25-152.22$ & ns \\
\hline $\mathrm{MCH}$ (pg) & 46.2 & $41.60-50.78$ & 45.5 & $40.15-50.88$ & 43.3 & $36.67-49.95$ & ns \\
\hline $\mathrm{MCHC}(\mathrm{g} / \mathrm{l})$ & 334.0 & $320.62-347.29$ & 331.3 & $319.02-343.50$ & 335.7 & $315.96-355.39$ & ns \\
\hline $\mathrm{WBC}\left(\times 10^{9} / 1\right)$ & $16.36^{\mathrm{a}, \mathrm{b}}$ & $11.696-21.020$ & $14.63^{\mathrm{a}}$ & $11.986-17.264$ & $21.67^{\mathrm{b}}$ & $16.535-26.799$ & $*$ \\
\hline
\end{tabular}

CI: 95\% confidence interval; LW: live weight; ns: non significant; RBC: red blood cells; HCT: haematocrit; HGB: haemoglobin; MCV: mean corpuscular volume; MCH: mean corpuscular haemoglobin; MCHC: mean corpuscular haemoglobin concentration; WBC: white blood cells.

*; a,b: Means within a row with different superscript letters differ at $(P<0.05)$. 
Table 4. Leukogram of fattened mallard ducks in relation to the diet.

\begin{tabular}{|c|c|c|c|c|c|c|c|}
\hline \multirow{3}{*}{ Item $(\%)$} & \multicolumn{6}{|c|}{ Diet } & \multirow{3}{*}{ Significance } \\
\hline & \multicolumn{2}{|c|}{ Control } & \multicolumn{2}{|c|}{ Experimental 1} & \multicolumn{2}{|c|}{ Experimental 2} & \\
\hline & Mean & S.E.M. & Mean & S.E.M. & Mean & S.E.M. & \\
\hline Number & \multicolumn{2}{|c|}{12} & \multicolumn{2}{|c|}{12} & \multicolumn{2}{|c|}{12} & \\
\hline GRA & \multicolumn{2}{|c|}{$36.33 \pm 2.200$} & \multicolumn{2}{|c|}{$35.67 \pm 2.805$} & \multicolumn{2}{|c|}{$36.58 \pm 3.513$} & ns \\
\hline LYM & \multicolumn{2}{|c|}{$61.42 \pm 2.288$} & \multicolumn{2}{|c|}{$61.75 \pm 2.722$} & \multicolumn{2}{|c|}{$62.58 \pm 3.456$} & ns \\
\hline MON & \multicolumn{2}{|c|}{$2.25^{b} \pm 0.494$} & \multicolumn{2}{|c|}{$2.58^{b} \pm 0.336$} & \multicolumn{2}{|c|}{$0.84^{\mathrm{a}} \pm 0.297$} & $*$ \\
\hline
\end{tabular}

S.E.M.: standard error of the mean; ns: non significant; GRA: granulocytes; LYM: lymphocytes; MON: monocytes *; a,b: Means within a row with different superscript letters differ at $(P<0.05)$.

expresses the proportion of erythrocytes from the total blood volume. The HCT value also serves to calculate the basic erythrocyte indices (MCV and $\mathrm{MCHC}$ ), while these indices are consequently used to partially evaluate the morphology of the erythrocytes and also the saturation level of haemoglobin in the erythrocyte. Particularly the MCV and MCHC can then be useful for determining an anaemia classification (Lassen and Weiser 2004; Tvedten 2010). Generally, it can be said that the values of $\mathrm{HGB}, \mathrm{MCV}, \mathrm{MCH}$, and MCHC found in our study were lower in comparison with the values found by Li et al. (2012) in 21-day-old Cherry Valley ducks and also by He et al. (2013); in our study, we found slightly lower values of $\mathrm{HGB}, \mathrm{MCV}$, and $\mathrm{MCH}$ in group $\mathrm{E} 2(P>0.05)$. In addition, within all the analysed dietary groups in our study, the HGB values are in accordance with the physiological values presented by Carpenter (2012) in the mallard ducks. The values of MCHC in our study are then in compliance with the values published by Mahmoud (2015) in 3-month-old ducks.

The determination of WBC and differential leukocyte counts are among one of the most important haematological examinations, providing us with information about the health condition of individuals. Values of WBC in respective groups of mallard ducks in our study were slightly lower than those found by Olayemi and Arowolo (2009) in adult Nigerian ducks in the dry season. On the other hand, the values of WBC in our study were slightly higher than those found by Olayemi et al. (2003) in 8-10-week-old Nigerian ducks and also by Olayemi and Arowolo (2009) in adult Nigerian ducks in the wet season.

The values of MON found in the groups $\mathrm{C}$ and $\mathrm{E} 1$ of our study correspond with the values presented by Campbell et al. (2010). A significantly lower value of MON in group E2 is similar to that found by Olayemi and Arowolo (2009) and also by Mahmoud (2015). Since there is a wide reference interval presented in literature for the values of MON percentage share in Anseriformes, it is necessary to assess adequately the findings with regard to the factors that could influence its proportion. Besides, MON is among the largest cells in bird blood and for this reason they can be identified sometimes mistakenly as LYM, especially as a large type of LYM (Doubek et al. 2003; Campbell et al. 2010; Saha and Geissmann 2011). Moreover, a significantly higher MON value (6.2\%) in 21-day-old Cherry Valley ducks was found by Li et al. (2012). These authors used an automatic blood counter analyzer to determine the individual leukocyte types (LYM, GRA, and MON). The considerably higher MON value and LYM value $(83.9 \%)$ presented in a study by Li et al. (2012) could be related more to the different method of determining differential leukocyte counts. In this regard, it can be stated that the comparison of values of leukogram found by the traditional manual enumeration based on morphological characteristics using a microscope with their values, which were determined by the automatic determination using an analyzer, can be sometimes greatly misleading. Such a comparison can affect negatively 
the intrinsic diagnostics process of the examined poultry. Moreover, recently there has been found that precise differentiation of avian leukocytes can be effectively performed by the flow cytometry method which identifies particular leukocyte subpopulations mainly on the basis of their different surface receptors (De Boever et al. 2010; Seliger et al. 2012; Bílková et al. 2017). Besides, our results of the differential leukocyte counts in Cherry Valley hybrid ducks showed that LYM are the most abundant type of leukocytes, which is in accordance with the previous findings of Li et al. (2012) and Eze et al. (2014). The LYM and GRA values found in our study are generally in accordance with those stated by Campbell et al. (2010) for mallard ducks, while their percentage shares did not differ from the respective groups of ducks in our study $(P>0.05)$.

With the exception of WBC, the mean values of the monitored haematological indicators within all 3 dietary groups in our study were found in their common physiological range defined for the mallard ducks. Based on the results of the haematological examination, it can be concluded that the replacement of soybean meal with meal from the Zulika variety of whole white lupin seeds in the diet did not have a negative effect on the determined blood indicators. Therefore, whole white lupin seeds were successfully used as an important protein component of the diet for the fattening of hybrid mallard ducks.

\section{Acknowledgements}

This study was funded from the Grant Project of the Ministry of Agriculture of the Czech Republic NAZV No. QJ1510136.

\section{References}

Bílková B, Bainová Z, Janda J, Zita L, Vinkler M 2017: Different breeds, different blood: Cytometric analysis of whole blood cellular composition in chicken breeds. Vet Immunol Immunopathol 188: 71-77

Brockus CV 2011: Erythrocytes. In: Latimer KS (ed): Duncan and Prasse's Veterinary Laboratory Medicine: Clinical Pathology, Wiley-Blackwell, Arnes, pp 3-44

Campbell TW, Smith SA, Zimmerman KL 2010: Hematology of waterfowl and raptors. In: Weiss DJ, Wardrop KJ: Schalm's Veterinary Hematology. Wiley-Blackwell, Arnes, pp 977-986

Carpenter JW 2012: Exotic animal formulary. Elsevier - Health sciences Division, Philadelphia, 744 p.

Chang W, Xie Q, Zheng A, Zhang S, Chen Z, Wang J, Liu G, Cai H 2016: Effects of aflatoxins on growth performance and skeletal muscle of Cherry Valley meat male ducks. Anim Nut 2: 186-191

De Boever S, Croubels S, Demeyere K, Lambrecht B, De Backer P, Meyer E 2010: Flow cytometric differentiation of avian leukocytes and analysis of their intracellular cytokine expression. Avian Pathol 39: 41-46

Doubek J, Bouda J, Doubek M, Fürll M, Knotková Z, Pejřilová S, Pravda D, Scheer P, Svobodová Z, Vodička R

2003: Veterinary Haematology (in Czech). Noviko, Brno, 464 p.

Eze PC, Okoye JO, Ogbonna IO, Ezema WS, Eze DC, Okwor EC, Okorie-Kanu C, Idika KI 2014: Comparative evaluation of the effects of velogenic Newcastle disease virus infection on the hematology of ducks and chicken. Open J Vet Med 4: 113-121

He J, Zhang KY, Chen DW, Ding XM, Feng GD. Ao X 2013: Effects of maize naturally contaminated with aflatoxin $\mathrm{B}_{1}$ on growth performance, blood profiles and hepatic histopathology in ducks. Livestock Sci 152: 192-199

Hernández AJ, Roman D 2016: Phosphorus and nitrogen utilization efficiency in rainbow trout (Oncorhynchus mykiss) fed diets with lupin (Lupinus albus) or soybean (Glycine max) meals as partial replacements to fish meal. Czech J Anim Sci 61: 67-74

Iqbal KJ, Ashraf M, Javid A, Khan N, Abbas F, Hafeez-ur-Rehman M, Rafique MK, Rasool F, Azmat H, Altaf M, Irfan 2016: Effect of different plant and animal origin (fishmeal) feeds on digestive enzyme activity and haematology of juvenile Labeo rohita. Pak J Zool 48: 201-207

Kaczmarek SA, Cowieson AJ, Hejdysz M, Rutkowski A 2016: Microbial phytase improves performance and bone traits in broilers fed diets based on soybean meal and containing lupin meal. Anim Prod Sci 56: 1669-1676

Knotková Z, Musilová A, Tukač V 2013: Rigours of clinical haematology of birds and reptiles (in Czech). In: Proceedings of Drobní savci, ptáci a plazi: Záludnosti diagnostiky a terapie a nejčastější zdravotní problémy malých a drobných zvířat, Czech Republic, pp 16-33

Král I, Suchý P 2000: Haematological studies in adolescent breeding cocks. Acta Vet Brno 69: 189-194

Lassen EDD, Weiser G 2004: Laboratory technology for veterinary medicine. In Thrall MA: Veterinary Hematology and Clinical Chemistry. Lippincott Williams and Wilkins, pp 3-37

Li Y, Liu YH, Yang ZB, Wan XL, Chi F 2012: The efficacy of clay enterosorbent to ameliorate the toxicity of aflatoxin $\mathrm{B}_{1}$ from contaminated corn (Zea mays) on hematology, serum biochemistry, and oxidative stress in ducklings. J Appl Poult Res 21: 806-815 
Mahmoud EA 2015: Hemato-biochemical and pathological changes on avian influenza in naturally infected domestic ducks in Egypt. Vet World 8: 1177-1182

Nalle CL, Ravindran V, Ravindran G 2012: Nutritional value of white lupins (Lupinus albus) for broilers: apparent metabolisable energy, apparent ileal amino acid digestibility and production performance. Animal 6: 579-585

Obun CO 2013: Impact of raw tallow Detarium microcarpum (guill and sperr) seed meal on performance and blood parameters in broilers. Iran J App Anim Sci 3: 289-294

Okeudo NJ, Okoli IC, Igwe GOF 2003: Hematological characteristics of duck (Cairina moschata) of Southeastern Nigeria. Tropicultura 21: 61-65

Olayemi F, Oyewale J, Rahman S, Omolewa O 2003: Comparative assessment of the white blood cell values, plasma volume and blood volume in the young and adult Nigerian duck (Anas platyrhynchos). Vet Archiv 73: 271-276

Olayemi FO, Arowolo ROA 2009: Seasonal variations in the haematological values of the Nigerian Duck (Anas platyrhynchos). Int J Poult Sci 8: 813-815

Osuigwe DI, Nwosu C, Ogunji JO 2007: Preliminary observations on some haematological parameters of juvenile Heterobranchus longifilis fed different dietary levels of raw and boiled jackbean (Canavalia ensiformis) seed meal. In: Proceedings of conference of international agricultural research development, Tropentag, University of Kassel-Witzenhausen and University of Göttingen, p. 6

Saha P, Geissmann F 2011: Multifunctional monocytes. Toward a functional characterization of blood monocytes. Immunol Cell Biol 89: 2-4

Seliger C, Schaerer B, Kohn M, Pendl H, Weigend S, Kaspers B, Haertle S 2012: A rapid high-precision flow cytometry based technique for total white blood cell counting in chickens. Vet Immunol Immunopathol 145: 86-99

Straková E, Suchý P, Večerek V, Šerman V, Mas N, Jůzl M 2006: Nutritional composition of seeds of the genus Lupinus. Acta Vet Brno 75: 489-493

Suchý P, Straková E, Herzig I, Steinhauser L, Vopálenský J, Kroupa L 2010: Effect of replacing soybean meal with lupin seed-based meal in chicken diet on performance, carcass value and meat quality. Acta Vet Brno 79: 195-202

Tvedten H 2010: Laboratory and clinical diagnosis of anemia. In Weiss DJ, Wardrop KJ: Schalm's veterinary hematology. Wiley-Blackwell, Arnes, pp 152-161

Zeng QF, Bai P, Wang JP, Ding XM, Luo YH, Bai SP, Xuan Y, Su ZW, Lin SQ, Zhao LJ, Zhang KY 2015: The response of meat ducks from 15 to $35 \mathrm{~d}$ of age to gossypol from cottonseed meal. Poult Sci 94: 1277-1286 